\title{
The use of environmental markers to identify groundwater salinization sources in a Neogene basin, Kert aquifer case, NE Morocco
}

\author{
M. Elgettafi • A. Elmandour • \\ M. Himi · A. Casas
}

Received: 31 December 2011/Revised: 6 April 2012/ Accepted: 9 October 2012/Published online: 28 February 2013

(C) Islamic Azad University (IAU) 2013

\begin{abstract}
Environmental isotopes data of oxygen and hydrogen of natural water and sulphur and oxygen of dissolved sulphate as well as characteristics of $d$-excess are used to illustrate the salinity origin in Kert aquifer NE Morocco. In this study, 14 groundwater samples and surface water of the Kert River were collected in the Kert plain during December 2008, and were combined with previously collected hydrochemical data. The isotope compositions of these waters range from -5.74 to $-4.51 \%$ for oxygen and from -40.8 to $-34.1 \%$ for hydrogen. In Kert River these values are $-6.47 \%$ for oxygen and $-47.56 \%$ for hydrogen. All the samples with a slope $<8$ do not fall on the meteoric water line indicating a light evaporation. Water has low and different $d$-excess values (ranging from +1.37 to $+9.82 \%$ ), reflecting different climatic conditions. Based on the nitrate concentration water in the Kert aquifer comes from the modern precipitation. The isotope compositions range from -2.2 to $+16 \%$ for sulphur and from +5.02 to $+13.86 \%$ for oxygen. In Kert River these values are -4.6 and $+5.3 \%$ for sulphur and oxygen, respectively. There are fairly
\end{abstract}

M. Elgettafi $(\bowtie) \cdot$ M. Himi · A. Casas

Department of Geochemistry, Petrology and Geological

Prospecting, Water Institute, University of Barcelona, 02028

Barcelona, Spain

e-mail: melgettafi@ub.edu

M. Elgettafi · A. Elmandour

Laboratory of Hydrogeology, Faculty of Sciences Semlalia,

Cadi Ayyad University, BP 2390 Marrakech, Morocco

M. Himi

National School of Applied Sciences, Mohammed Premier

University, BP 3, Ajdir, Al Hoceima, Morocco constant difference between oxygen of water and the oxygen of sulphate suggesting a dominant control of this latter in sulphate sources. At least three major sulphate sources were identified by the isotope data from sulphate in these waters: (1) dissolved marine sulphate from the underlying upper Miocene unit; (2) dissolved sulphate from Kert River; (3) sulphate derived from oxidation of sulphur compounds in the metamorphic massif of Temsamane. The latter has a dilution role. The isotopic variations of these waters and sulphate concentration therein reflect mixing of these sources in the aquifer.

Keywords NE Morocco - Kert aquifer - Kert River . Stable isotopes - Upper Miocene - Water salinity

\section{Introduction}

In the Kert basin, groundwater constitutes most of the water resources. The aquifer is used by several economical sectors, like drinking water from Tafersite sector and irrigation. But groundwater salinization is a major limitation for economical development of the region.

Because stable isotopes oxygen and hydrogen or deuterium $\left({ }^{18} \mathrm{O}\right.$ and ${ }^{2} \mathrm{H}$ or $\mathrm{D}$, respectively) have conservative properties and depend only on atmospheric conditions during recharge (Gat 1971), groundwaters are particularly suitable to investigate the relationship between isotopic elements as a tool in applied hydrogeochemical studies. So, the movement of water through the soil into aquifers is invariant with respect to its isotopic $\left({ }^{18} \mathrm{O}\right.$ and $\left.{ }^{2} \mathrm{H}\right)$ composition except as regards mixing with other water bodies. Oxygen and hydrogen are commonly used to study the origin of groundwater salinity. The deuterium excess ( $d$-excess $\left.=\delta^{2} \mathrm{H}-8 \delta^{18} \mathrm{O}\right)$ is largely used for describing 
the conditions that lead to kinetic isotope fractionation between water and vapour during primary evaporation in the oceans (Dansgaard 1964). On the global scale, the $d$ value is close to 10 for meteoric waters due to slower diffusion of $\mathrm{H}_{2}^{18} \mathrm{O}$ relative to $\mathrm{H}_{2}^{16} \mathrm{O}\left(D\left(\mathrm{H}_{2}^{18} \mathrm{O}\right) / D\left(\mathrm{H}_{2}^{16} \mathrm{O}\right)=\right.$ 0.9691) than $\mathrm{HD}^{16} \mathrm{O}$ relative to $\mathrm{H}_{2}^{16} \mathrm{O}\left(D\left(\mathrm{HD}^{16} \mathrm{O}\right) /\right.$ $\left.D\left(\mathrm{H}_{2}^{16} \mathrm{O}\right)=0.9839\right)$ during evaporation occurring at the air-sea interface as demonstrated by Cappa et al. (2003).

In cases where the isotopic compositions are accompanied with lowering of $d$-excess values, it means an increase of aridity (Gat 1995). Groundwater across the Sahara, northern Africa and in the arid zones has low $\delta^{18} \mathrm{O}, \delta^{2} \mathrm{H}$, and $d$-excess values $(\leq 10 \%)$ relative to modern precipitation in these regions ( $d$-excess $>16 \%$ ) (Clark and Fritz 1997; Sultan et al. 1997).

The global water cycle exerts a major influence on the ${ }^{2} \mathrm{H}$ and ${ }^{18} \mathrm{O}$ isotope composition of natural waters. Global precipitation falls on the meteoric water line (MWL) with a slope of 8 . Deviation from a slope of 8 on a plot of $D$ versus ${ }^{18} \mathrm{O}$ may indicate evaporation, mixing between different water groups, or water-rock interactions. However, in most arid and semi arid environments, the isotope data of meteoric waters line do not fall on the MWL and the slope of the linear correlation between $D$ and ${ }^{18} \mathrm{O}$ values is generally $<8$. This is because of non-equilibrium isotope fractionation during evaporation, which does not follow a Rayleigh type distillation (Gonfiantini 1986). Because ground-water systems are complex, it is not always possible to constrain the sources of the water salinity using only ${ }^{18} \mathrm{O}$ and $D$ (Eastoe et al. 2010). A better understanding of these sources may be obtained by adding information on the isotopic compositions of the dissolved constituents of the groundwater such as sulphur $\left({ }^{34} \mathrm{~S}\right)$ and oxygen $\left({ }^{18} \mathrm{O}\right)$ isotopes. Dissolved sulphate $\left(\mathrm{SO}_{4}{ }^{2-}\right)$ in groundwater can have different origins: (1) those related to bedrock from dissolution of evaporate; (2) marine aerosol and secondary $\mathrm{SO}_{4}{ }^{2-}$ formed via $\mathrm{S}$ oxidation; and (3) anthropogenic sources such as fertilisers and mine drainage. Dissolution of evaporate sulphates would affect the sulphur isotopic composition of water. The $\delta^{34} \mathrm{~S}$ values of marine sulphate varied over geological time (Claypool et al. 1980). Several studies have applied the dual approach of $\mathrm{O}$ isotopic composition of dissolved $\mathrm{SO}_{4}{ }^{2-}$ coupled with $\mathrm{S}$ isotopes to better characterise the sources of dissolved $\mathrm{SO}_{4}{ }^{2-}$ in groundwater (Dogramaci et al. 2001; Berner et al. 2002; Moller et al. 2007). No work has been done on the isotopic composition of groundwaters through the mineralised district of the northeastern Morocco. Groundwater data in this paper are reported from two sources (1) new isotopic results from groundwater and Kert River; and (2) previously published hydrochemical data (Elgettafi et al. 2011). The latter shows that continuous dissolution of halite and gypsum of upper Miocene unit is the potential source of groundwater salinity. Recent research (Elgettafi et al. 2012) has found that the groundwater salinity progressively increases along flow paths towards the southern and eastern Kert aquifer (Fig. 3). This increase in salinity has been attributed principally to chloride, sodium, calcium, magnesium and sulphate $\left(\mathrm{Cl}^{-}, \mathrm{Na}^{+}, \mathrm{Ca}^{2+}, \mathrm{Mg}^{2+}\right.$ and $\mathrm{SO}_{4}{ }^{2-}$, respectively). Generally, in most parts of the Kert plain, the salinity of the groundwater is high. In the Driouch southern plain, for example, the level of the total dissolved solids (TDS) exceeds $10,000 \mathrm{mg} / \mathrm{L}$. Likewise; groundwater from the Midar in western plain is highly mineralized with TDS about $11,000 \mathrm{mg} / \mathrm{L}$. However, the salinity of groundwater from Tafersite region in the northern plain is low with TDS not exceeding $600 \mathrm{mg} / \mathrm{L}$. In December 2008 stable isotopic measurements were made on 14 water samples collected from wells and one sample from Kert River. Our aim is to elucidate the origin of salinity in water, because this is crucial for water management and remediation. The advantages of this multi-isotope approach are demonstrated in the present paper for the case study of the Kert plain located in northeastern Morocco.

\section{Geological setting}

The Kert basin, which covers a total area of about $250 \mathrm{~km}^{2}$, is located in the northeastern part of Morocco and extends between latitudes $34^{\circ} 55^{\prime}$ and $35^{\circ} 54^{\prime} \mathrm{N}$, and longitudes $3^{\circ} 19^{\prime}$ and $3^{\circ} 34^{\prime} \mathrm{W}$ (Fig. 1). The Kert River is the important river in the Kert basin, which is mostly characterized by a seasonal flow regime. This stream with a total long rounded $90 \mathrm{~km}$ and a catchments area rounded $2,710 \mathrm{~km}^{2}$ (Zielhofer et al. 2008). During the Miocene to Villafranchian, the Kert depression received mixed and varied thick marine and continental sedimentation. It is limited to the east by the western Gareb range. The metamorphic massif of Temsamane which limits the plain in the north and northwest was affected by a compressive tectonic event generating a $\mathrm{N} 120^{\circ} \mathrm{E}$ fracture cleavage associated with green shale (Frizon de Lamotte 1985). In the south part we found intra rifain nappes and marls of Miocene. The Jurassic and Cretaceous deposits mostly constitute of carbonates rocks; limit the plain in the south part (Fig. 1). Several studies have been done to date the opening of Kert basin. During early-middle Tortonian a series of conjugate strike-slip faults $\left(\mathrm{N} 70^{\circ} \mathrm{E}-\mathrm{N} 90^{\circ} \mathrm{E}\right)$ occurs east of Nekor fault, related 


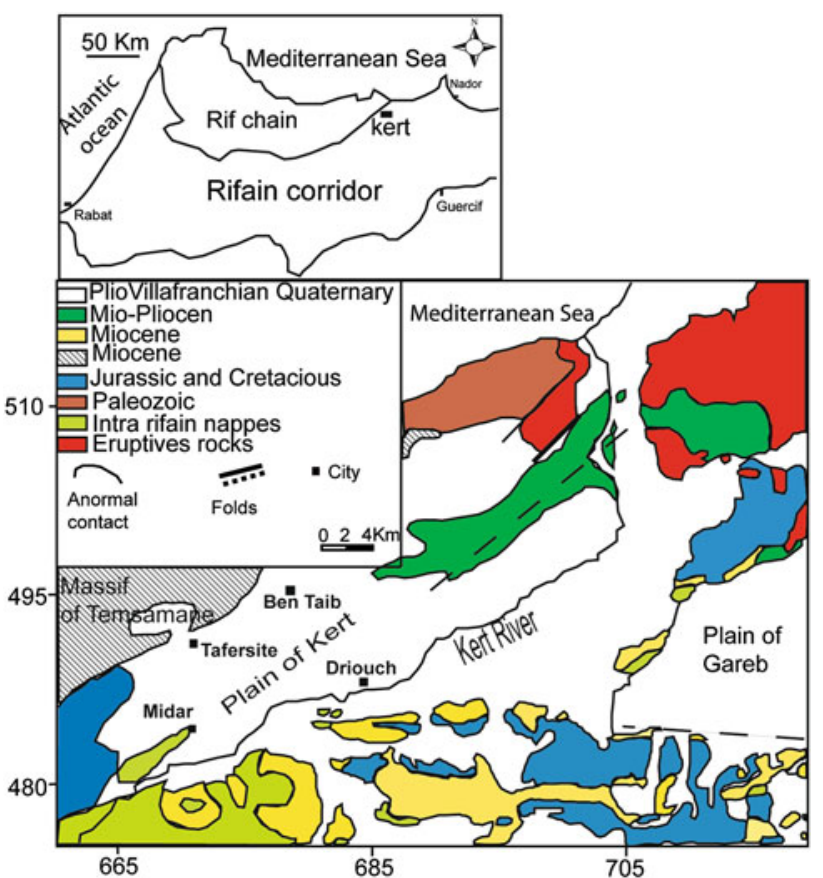

Fig. 1 Geological map of middle Kert plain (after Carlier 1973)

to the formation of Kert basin (Ait Brahim et al. 2002). While other study suggests that the younger normal fault system records $\mathrm{N}-\mathrm{S}$ extension controlling the formation of the Kert basin dates the Messinian-Pliocene age (Azdimousa et al. 2007). In the Messinian, Kert basin deepened with the Messinian Sea level rise (Haq et al. 1987). It is known that in the occidental Mediterranean Neogene basin, the sedimentological history is marked by evaporite series related to messinian salinity crisis caused by closing of Gibraltar strait (Rouchy and Caruso 2006). Whereof, a complex tectono-sedimentary (Gareb-Kebdana chaotic unit) extending from Kebdana in the east towards the Midar city in the west often composed by a gypseous marl was defined in the region (Hervouet 1985). In the west of plain, the scrapes were principally a fragment of gravity-driven nappes of internal and external rifain domain slided westward along the foreland (Hervouet 1985). The plain contains transgressed postnappe deposits (Azdimousa 1999). The micropaleontological dating of the sedimentary filling the Kert basin indicates late Miocene and Pliocene ages (Feinberg 1986).

\section{Hydrogeological setting}

The hydrogeology characteristic of the study area was described by Carlier (1973), based on data obtained from pumping tests and electrical geophysics. The strata of various hydrogeological formations can be identified as follows (Fig. 2). The substratum of the aquifer is represented by upper Miocene transgressed marls, which is overlaid by a contemporary deposit made up of limestone and conglomerate. We assume that the Miocene formation contains the gypsum as well as the one outcrop in the region. The series end with gravel, silt and clay Villafranchian age. Two vertical faults have controlled the Kert basin during the Miocene. These faults have collapsed the centre of the plain and have raised the north and south borders. Consequently, the aquifer might be hydraulically connected through those faults with the underlying Jurassic unit. Two knowledge boreholes were drilled in this latter
Fig. 2 Hydrogeological crosssection in the Kert plain (Carlier 1973)
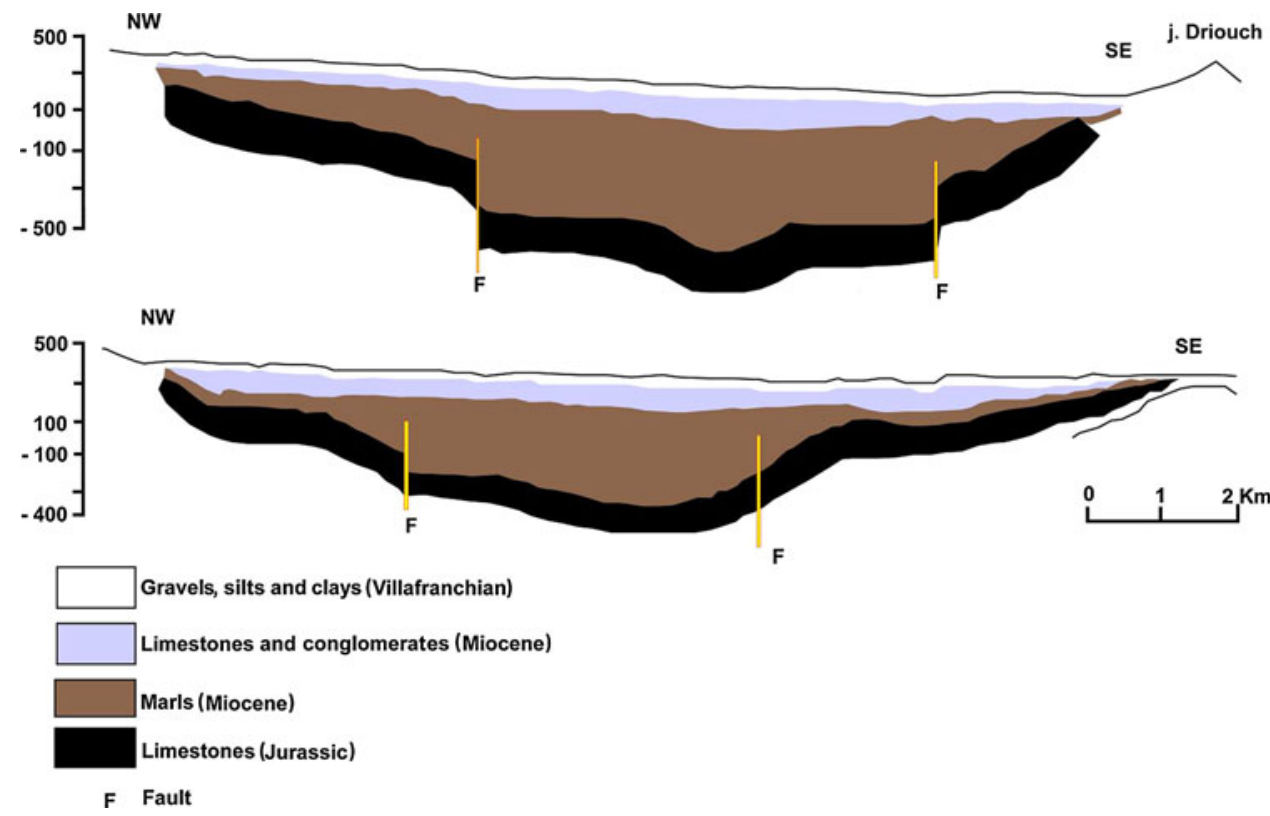
unit to find an aquifer in the deep resisting formation determined by geophysics (Zeryouhi 1971). The first borehole number is $1635 / 6$ with the depth of $801 \mathrm{~m}$ ( $X=685.18, Y=486.85$ Lambert coordinates) and the second borehole number is $1636 / 6,684 \mathrm{~m}$ in depth ( $X=679.14, Y=484.05$ Lambert coordinates). Both of them had not given the expected result. Thirty-two pumping tests were performed on the plain. Permeability and transmissivity computed using classical Theis-Jacob method amount from $0.4 \times 10^{-5}$ to $18 \times 10^{-5} \mathrm{~m} / \mathrm{s}$ and from $0.1 \times 10^{-3}$ to $34 \times 10^{-3} \mathrm{~m}^{2} / \mathrm{s}$, respectively. Storage coefficient estimated from these tests is $0.3-3.5 \%$. The piezometric head contour map realized in 2008 (Elgettafi 2011) shows that in northern part water flows from Northwest to Southeast. The second water flow as the major direction is from West to East in the centre plain. Temsamane massif metamorphic located on the northwestern side is considered as recharge zone for the studied groundwater. The discharge fields are situated in the extreme East. Kert River is characterized by a seasonal flow regime and it is in connection with aquifer.

\section{Materials and methods}

Samples of groundwater and river were collected during December 2008 (Fig. 3; Table 1). Methods of collection and analysis of water samples followed are essentially the same as given by APHA (1985). Samples were collected in $1 \mathrm{~L}$ capacity polythene bottles. Prior to the collection, bottles were thoroughly washed with diluted $\mathrm{HNO}_{3}$ acid, and then with distilled water in the laboratory before filling bottles with samples. Each bottle was rinsed to avoid any possible contamination in bottling and every other precautionary measure was taken. Electrical conductivity (EC) was measured on site by a VWR EC300 instrument, previously calibrated by the conductivity solution HI 70031 . Samples were stored at $4{ }^{\circ} \mathrm{C}$. Prior to analysis, samples

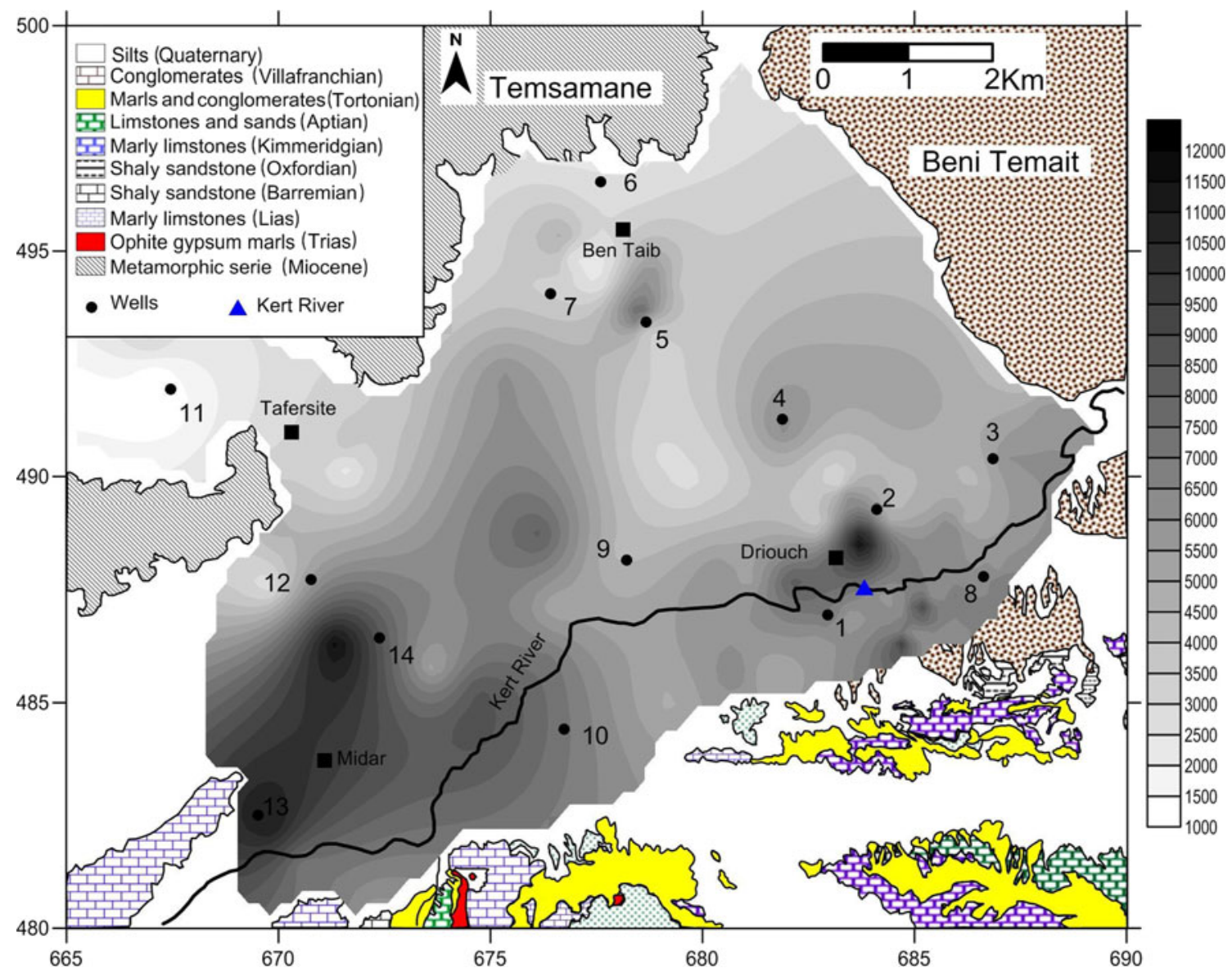

Fig. 3 Spatial distribution of electrical conductivity of groundwater (Elgettafi et al. 2011) and location of wells and Kert River sampled in this study 
Table 1 Isotopes analysis $\left({ }^{18} \mathrm{O},{ }^{2} \mathrm{H}\right.$ and ${ }^{34} \mathrm{~S}_{\mathrm{SO}_{4}}$ and ${ }^{18} \mathrm{O}_{\mathrm{SO}_{4}}$ ), chemical analysis in $\mathrm{mg} / \mathrm{L}$ (sodium, chloride, sulphate and nitrate) and electrical conductivity in $\mu \mathrm{s} / \mathrm{cm}$

\begin{tabular}{|c|c|c|c|c|c|c|c|c|c|c|c|}
\hline ID & ${ }^{18} \mathrm{O} \%$ & ${ }^{2} \mathrm{H} \% 0$ & ${ }^{34} \mathrm{~S}_{\mathrm{SO}_{4}} \% 0$ & ${ }^{18} \mathrm{O}_{\mathrm{SO}_{4}} \% 0$ & $\mathrm{Na}^{+}$ & $\mathrm{CI}^{-}$ & $\mathrm{SO}_{4}{ }^{2-}$ & $\mathrm{NO}_{3}{ }^{-}$ & EC & Slope & $d$-Excess $\% 0$ \\
\hline 1 & -5.61 & -36.6 & 0 & +7.21 & 822.1 & 1,153 & 1,397 & 66 & 5,670 & 6.52 & +8.28 \\
\hline 2 & -5.61 & -40.8 & +6.1 & +8.03 & 842.6 & 1,122 & 666 & 35 & 5,050 & 7.25 & +4.16 \\
\hline 3 & -5.74 & -36.1 & +7.2 & +8.76 & 792.2 & 974 & 639 & 30 & 4,680 & 6.28 & +9.82 \\
\hline 4 & -4.96 & -37.2 & +10 & +7.63 & 1,189 & 1,867 & 1,168 & 36 & 6,990 & 7.5 & +2.48 \\
\hline 5 & -5.24 & -36.8 & +16 & +13.86 & 1,658 & 1,289 & 1,462 & 0 & 7,420 & 7 & +5.20 \\
\hline 6 & -5.13 & -34.1 & +3.5 & +7.77 & 148.5 & 243 & 107 & 27 & 1,330 & 6.63 & +7.02 \\
\hline 7 & -5.34 & -35.6 & +5.6 & +5.02 & 580.9 & 458 & 248 & 12 & 2,830 & 6.65 & +7.20 \\
\hline 8 & -4.85 & -36.9 & -0.4 & +6.31 & 885.9 & 1,517 & 1,316 & 96 & 6,200 & 7.59 & +1.92 \\
\hline 9 & -5.15 & -36.2 & +6.8 & +8.64 & 664 & 739 & 428 & 17 & 3,690 & 7.02 & +5.03 \\
\hline 10 & -5.35 & -35.2 & +2 & +6.33 & 881.4 & 1,064 & 1,435 & 18 & 5,080 & 6.61 & +7.28 \\
\hline 11 & -5.57 & -37.4 & -2.2 & +5.79 & 55.25 & 86 & 134 & 18 & 850 & 6.71 & +7.19 \\
\hline 12 & -5.52 & -40.2 & +8.3 & +6.78 & 172.4 & 64 & 55 & 24 & 1,020 & 7.57 & +3.64 \\
\hline 13 & -4.5 & -34.7 & -1.4 & +8.21 & 546.6 & 758 & 1,063 & 94 & 4,120 & 7.69 & +1.30 \\
\hline 14 & -5.28 & -37.5 & +8.7 & +6.54 & 634.3 & 1,121 & 512 & 65 & 4,520 & 7.08 & +4.79 \\
\hline Kert River & -6.47 & -47.6 & -4.6 & +5.3 & 3,830 & 485.3 & 1,476 & 21 & 3,828 & 7.35 & +4.20 \\
\hline
\end{tabular}

were filtered with a Millipore filter of $45 \mu \mathrm{m}$ pore size. Major anion chloride, sulphate and nitrate $\left(\mathrm{Cl}^{-}, \mathrm{SO}_{4}{ }^{2-}\right.$ and $\mathrm{NO}_{3}{ }^{-}$, respectively) were analysed by HP liquid chromatography. Concentration of sodium $\left(\mathrm{Na}^{+}\right)$was determined by ICP-OES.

The $\delta D$ and $\delta^{18} \mathrm{O}$ of water were obtained by $\mathrm{H}_{2}$ and $\mathrm{CO}_{2}$ equilibrium, respectively, and isotope ratio mass spectrometry (IRMS) with a delta S Finnigan Mat. For S and O isotope analysis, the dissolved $\mathrm{SO}_{4}{ }^{2-}$ was precipitate as $\mathrm{BaSO}_{4}$ by the addition of $\mathrm{BaCl}_{2} \cdot 2 \mathrm{H}_{2} \mathrm{O}$, after acidifying the sample with $\mathrm{HCl}$ and boiling it to prevent $\mathrm{Ba}\left(\mathrm{CO}_{3}\right)_{2}$ precipitation. The $\mathrm{S}$ isotopic composition was determined with an Elemental Analyser (Carlo Ebra 1108) coupled with an IRMS (Delta C Finnigan Mat) and the O isotopic composition was analysed with a thermo-chemical elemental analyser (TC/EA Thermo-Quest Finnigan) coupled with an IRMS (Delta C Finnigan Mat). Notation is expressed in terms of $\delta \%$ relative to Vienna Standard Mean Ocean Water (V-SMOW) and Vienna Cañon Diablo Troilite (V-CDT) standards. The isotope ratios were calculated using international and internal laboratory standards. Reproducibility of the simples calculated from standards systematically interspersed in the analytical batches is $\pm 0.5 \%$ or $\delta D, \pm 0.2 \%$ for $\delta^{18} \mathrm{O}_{\mathrm{H}_{2} \mathrm{O}}, \pm 0.2 \%$ for $\%{ }^{34} \mathrm{~S}$, and $\pm 0.5 \%$ for $\delta^{18} \mathrm{O}_{\mathrm{SO}_{4}}$. All samples for isotopic analyses were prepared and analysed at the Scientific-Technical Services of the University of Barcelona.

Stable isotope ratios are reported in part per thousand (\%o) using the conventional delta notation:

$\delta_{\text {sample }} \%=\left[\left(R_{\text {sample }}-R_{\text {standard }} / R_{\text {standard }}\right)\right] \times 1,000$ where $R$ represents the ${ }^{34} \mathrm{~S} /{ }^{32} \mathrm{~S},{ }^{18} \mathrm{O} /{ }^{16} \mathrm{O}$ and ${ }^{2} \mathrm{H} /{ }^{1} \mathrm{H}$ ratios of the samples and the standards, respectively.

\section{Results and discussion}

Oxygen and hydrogen isotope composition

The $\delta^{18} \mathrm{O}$ and $\delta^{2} \mathrm{H}$ compositions of groundwater range from -5.74 to $-4.51 \%$ and from -40.8 to $-34.1 \%$, respectively. Regular measurements of $\delta D$ and $\delta^{18} \mathrm{O}$ in rainfall in the study area do not exist. So the nearest relevant IAEA/ WMO (2006) GNIP station is Bab Bou Idir mountain station $(1,200 \mathrm{~m})$ for which there is a continuous temporal

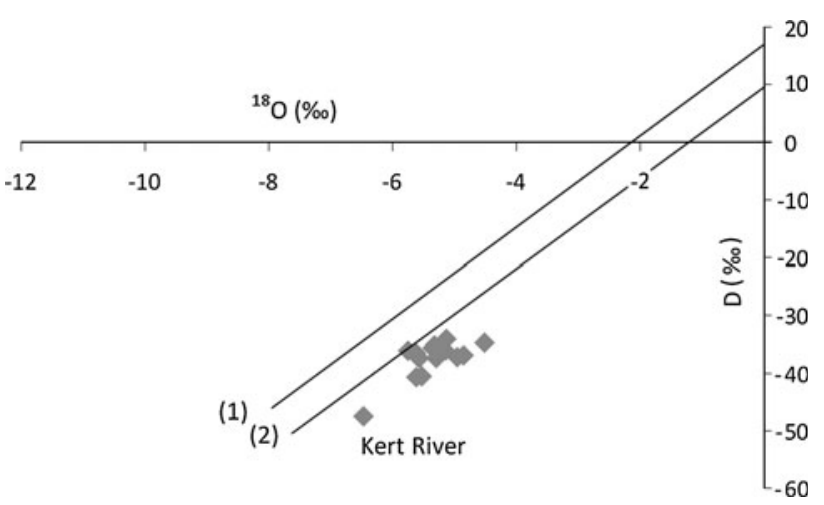

Fig. 4 Isotope $\delta D-\delta^{18} \mathrm{O}$ compositions of the groundwater and Kert River in the study area. 1 Bab Bou Idir local water line, 2 World meteoric water line 
record of monthly means of $\delta^{18} \mathrm{O}$ and $\delta^{2} \mathrm{H}$ for rainfall. In the $D$ versus $\delta^{18} \mathrm{O}$ diagram (Fig. 4), all the water wells and Kert River are not situated along the WML $(\delta D \%=$ $\delta^{18} \mathrm{O} \%$ + 10) defined by Craig (1961) and neither along the Bab Bou Idir Local Water Line $(\delta D \%=$ $7.34 \delta^{18} \mathrm{O} \%$ + 16.52).

It is showed that evaporation slopes are lower for low humidity conditions and higher for high humidity (Gat 1981). We have calculated the slope using the data from the Kert aquifer. The data show that this parameter ranges from 6.28 to $7.59 \%$ with $7.35 \%$ in Kert River. All the samples of groundwater and Kert River show slopes $<8$ (Table 1). According to the conventional interpretation this result may reflect evaporation during or after rainfall infiltration and/or mixing with an external water source.

Arid conditions cause substantial evaporation of irrigation water prior to infiltration. Strong influence of evaporation on recharging irrigation water is inferred from the offset in values of $\delta^{2} \mathrm{H}$ and $\delta^{18} \mathrm{O}$ towards the right of the WML. Another reason for isotopic difference with Bab Bou Idir isotopic composition is probably due to the fact that Kert plain may receive more continental rains compared with the mountainous station.

The Kert River is normally dry; however, during the winter season a significant flow results through the plain into Mediterranean Sea. The isotopic value for this sample is quite variable for those of groundwater and probably reflects variation in the isotopic composition of the numerous storms which crossed the area during this season.

We attempt to use differences in $d$-excess parameter to determine climatic conditions of groundwater recharge. The data show that this parameter ranges from $+1.30 \%$ (no. 13) to $+9.82 \%$ (no. 1) (Table 1). The sample numbers 6,7 and 11 with low salinity and locating in the piedmont of Temsamane massif in north plain exhibit a similar $d$-excess $(\sim+7 \%)$. That implies the common groundwater origin from Temsamane metamorphic massif. However, this parameter presents a remarkable difference (between +1.30 and $+9.82 \%$ ) in the rest of samples with high salinity. It was significantly lower than $10 \%$, the value estimated by Craig (1961) for global meteoric waters. The reason behind this decrease of the $d$-excess value in this region is probably formed under different climatic conditions or at least from different moisture sources. Also, this difference in $d$-excess values in the groundwater may be a function of isotope fractionation degrees during evaporation. In North-West Sahara Aquifer System (NWSAS), the $d$-excess values in Tunisia range from 1 to $10 \%$ and from -1 to $+11 \%$ in Algerian, which indicate a present day recharge (Algamal 2011).
We have calculated $d$-excess and slope from isotopic data (Chaouni Alia 2001) of groundwater from unconfined aquifer of Bou Areg in northeastern Morocco which is close to the Kert aquifer. Values of $d$-excess range from 2.2 to $+6.72 \%$ and the slope rang from 6.63 to 8.46. Those values from North Africa show a significant similarity with our own.

In northeastern Negev aquifer at East part of Mediterranean Sea modern precipitation is characterized by $d$ excess values in the range of 15-25\% (Levin et al. 1980). This result is interpreted as a present day recharge (Vengosh et al. 2007), because in this aquifer low $d$-excess values around $10 \%$ indicate palaeo-recharge ( $>30 \mathrm{ka} \mathrm{PB}$ ), while higher $d$-excess values $(>20 \%$ ) indicate modernday recharge (Yechieli et al. 1992). In our case, with absence of absolute age it is difficult to estimate the recharge age of groundwater in Kert aquifer; however, regarding the high concentration of $\mathrm{NO}_{3}{ }^{-}$(Table 1); we can attribute the groundwater in Kert aquifer at a present day recharge or at least a mixture with a palaeo-recharge water.

Finally, groundwaters have almost the same isotopic signature and a wide different salinity, which reveal that evaporation mechanism is not sufficient to explain the increasing salinity in Kert aquifer. Following, we use the sulphur isotopes to explain the origin of groundwater salinity in Kert aquifer.

Oxygen and sulphur isotope composition of sulphate

\section{Oxygen isotopes}

The oxygen isotope data for sulphate extracted from 14 water samples collected in Kert plain varied from +5.02 to $+13.86 \%$ (Table 1). Figure 5 shows the oxygen isotope compositions of the dissolved sulphate species relative to those of waters from which the sulphate was extracted. The data indicate that the $\delta^{18} \mathrm{O}_{\mathrm{SO}_{4}}$ values of the sulphate in the waters are a function of the sulphate sources and not the waters, because sulphates formed via sulphide oxidation must show a relationship between $\delta^{18} \mathrm{O}_{\mathrm{SO}_{4}}$ and $\delta^{18} \mathrm{O}_{\mathrm{H}_{2} \mathrm{O}}$ (Otero et al. 2008), as water is the source of $50-100 \%$ of the $\mathrm{SO}_{4}{ }^{2-}$ oxygen. There is no correlation between $\delta^{18} \mathrm{O}_{\mathrm{SO}_{4}}$ values of the dissolved sulphate and $\delta^{18} \mathrm{O}_{\mathrm{H}_{2} \mathrm{O}}$. Likewise, the values are not those of atmospheric $\mathrm{O}_{2}$. If there were strong water or atmospheric controls, the isotope data of the sulphate should fall on or near either the 1:1 line or the atmospheric $\mathrm{O}_{2}$ line in Fig. 5. Therefore, the dominant control of $\delta^{18} \mathrm{O}$ of $\mathrm{SO}_{4}{ }^{2-}$ (aq) appears to be the original sulphate sources. It is also noted from Fig. 5 that most of 


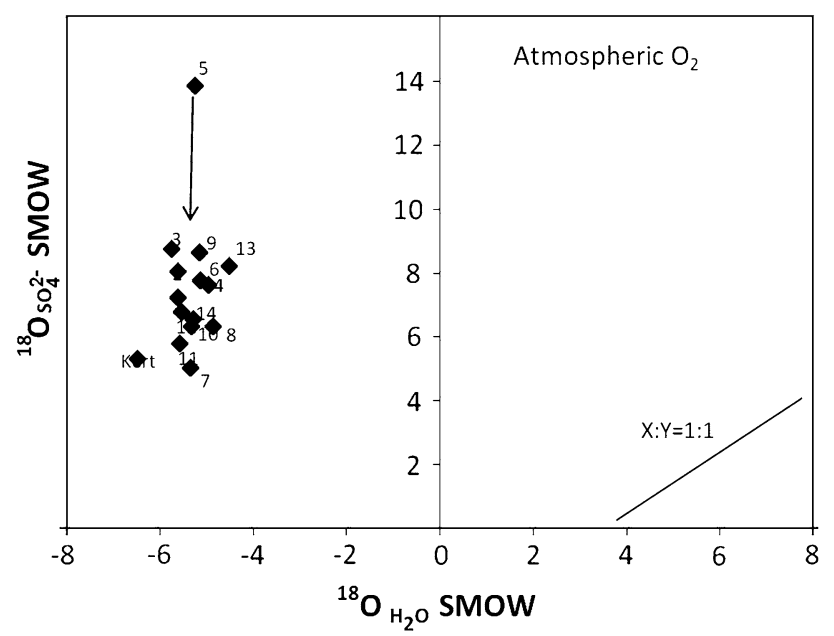

Fig. 5 Plot of $\delta^{18} \mathrm{O}_{\mathrm{SO}_{4}}$ versus $\delta^{18} \mathrm{O}_{\mathrm{H}_{2} \mathrm{O}}$ of groundwater and Kert River in Kert plain

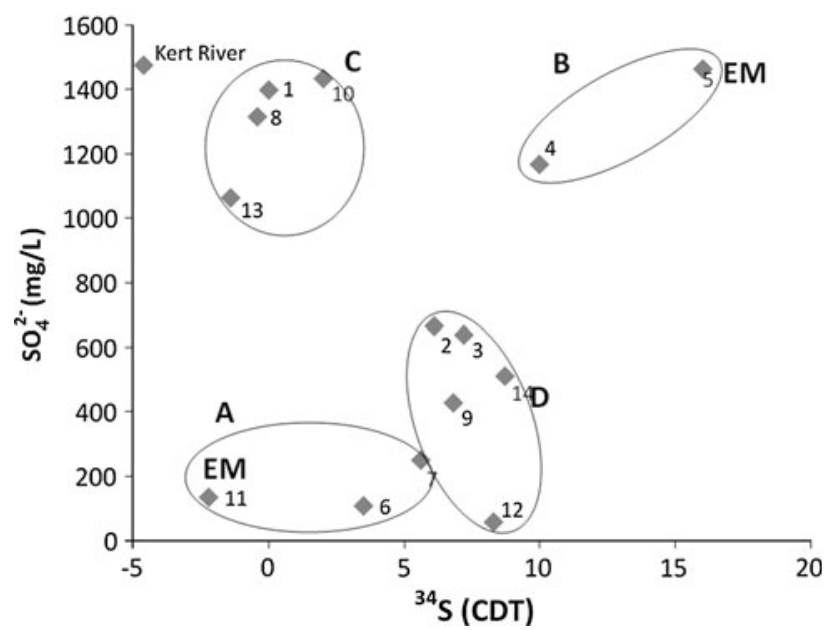

Fig. 6 Plot of $\delta^{34} \mathrm{~S}$ versus $\mathrm{SO}_{4}{ }^{2-}$ concentration of groundwater and Kert River in Kert plain, $E M$ end member

the sulphate has $\delta^{18} \mathrm{O}$ values within the range of marine sulphate.

\section{Sulphur isotopes}

Isotope measures have been done on 14 well samples and one Kert River. The isotopic characteristics of the investigated water samples varied widely (Table 1) and were used to group the samples into several categories. Water grouping was based on $\mathrm{SO}_{4}{ }^{2-}$ concentrations, $\delta^{34} \mathrm{~S}$ and geographical distribution (Fig. 6). The observations suggest that there are four major types of groundwater isotopically distinguished in the Kert aquifer. So, $\delta^{34} \mathrm{~S}$ from dissolved sulphate allows proposing four geochemical basins (A, B, C and D).
Group A (wells no. 6, 7 and 11) along the northern boundary of the plain that is near the Temsamane metamorphic massif (Fig. 3). The groundwater is low saline with sulphate concentrations $<300 \mathrm{mg} / \mathrm{L}$, a wide range of $\delta^{34} \mathrm{~S}$ values between -2.2 and $+6 \%$, and $\delta^{18} \mathrm{O}_{\mathrm{SO}_{4}}$ varies between +5.02 and $+7.77 \%$. In this case, well 11 represents the groundwater coming laterally from the Temsamane metamorphic massif and may represent a possible end member for the freshwater groundwater in the aquifer $(850 \mu \mathrm{s} / \mathrm{cm})$. We can suppose that dissolved sulphate is partially derived from oxidation of sulphides compounds, like pyrite which may be in the metamorphic rocks of Temsamane. Referring to the piezometric map (Elgettafi 2011) and geographical distribution, water in wells 6 and 7 is a mixture between the water originating from the metamorphic massif of Temsamane and aquifer waters.

Group B (wells no. 4 and 5) located in the centre of the plain, is the richest area in isotopic elements, the values of $\delta^{34} \mathrm{~S}$ range from +10 to $+16 \%$ and $\delta^{18} \mathrm{O}_{\mathrm{SO}_{4}}$ varies between +7.63 and $+13.86 \%$. The groundwater is saline with the highest $\mathrm{Cl}^{-}, \mathrm{Na}^{+}$and $\mathrm{SO}_{4}{ }^{2-}$ contents reported in this study. From these results, the high values seem to be the consequence of local dissolution of messinian evaporates rocks, with a little influence of water coming from the north. Moreover, these values are in agreement with high sulphate concentration $(1,300 \mathrm{mg} / \mathrm{L}$ average value). Therefore, well no. 5 is a possible end member for the saline groundwater in that aquifer.

Group C (wells 1, 8, 10 and 13) is in the right bank of the Kert River, in the south of the plain characterised by high salinity. The values range from -1.4 to $+2 \%$ and from +6.31 to $+8.28 \%$ for ${ }^{34} \mathrm{~S}$ and $\delta^{18} \mathrm{O}$, respectively. Isotopically, this group is closer to the isotopic signature of Kert River. The waters of these wells are characterized by high sulphate concentration $(1,300 \mathrm{mg} / \mathrm{L}$ in average) like Kert River. Most of sulphate is of marine origin; the high amounts of sulphate indicate that this cannot be of atmospheric origin or any other one. The water from these wells is in connection with Kert River, reflecting thus variation in the isotopic composition of the lands at different ages and numerous storms which crossed the area during winter season.

In Group D (wells 2, 3, 9, 12 and 14), the values of $\delta^{34} \mathrm{~S}$ and $\delta^{18} \mathrm{O}$ vary between +6.1 and $+8.7 \%$ and from +6.54 and $+8.76 \%$, respectively. The sulphate concentration is about $600 \mathrm{mg} / \mathrm{L}$ except the concentration of 12 well, which is about $55 \mathrm{mg} / \mathrm{L}$. This group is in the left bank of the Kert River. These waters are both influenced by waters coming from the metamorphic massif of Temsamane (well 12) and dissolution of messinian evaporates. 


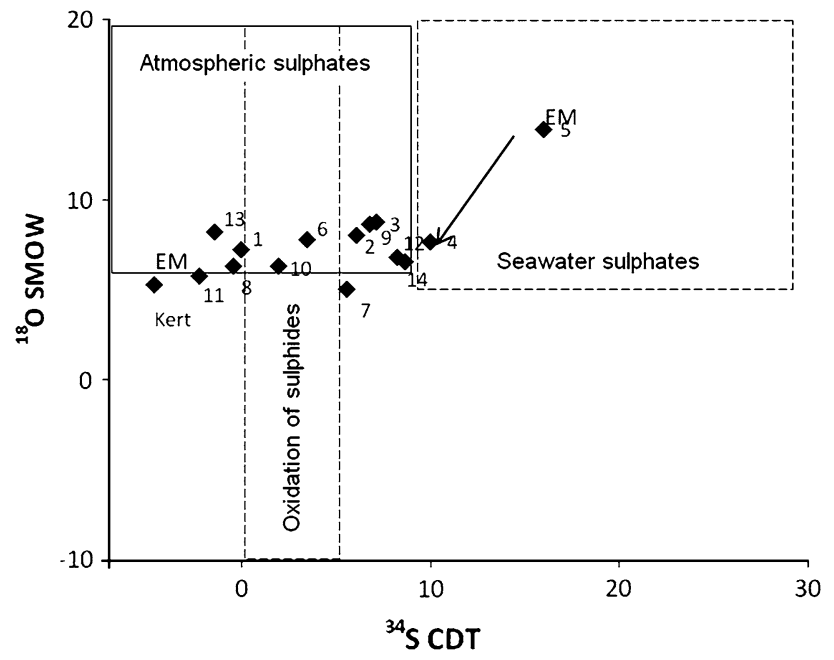

Fig. 7 Cross plot of $\delta^{34} \mathrm{~S}$ versus $\delta^{18} \mathrm{O}_{(\mathrm{SO} 4)}$ of groundwater and Kert River in Kert plain. Arrays are taken from Krouse and Mayer (1999), $E M$ end member

As shown in the diagram ${ }^{34} \mathrm{~S}$ versus ${ }^{18} \mathrm{O}$ (Fig. 7) one isotopically distinct sulphate source is the water of well no. 5 , which has relatively high value of $\delta^{34} \mathrm{~S}(+16 \%)$ which are similar to those of ancient marine sulphate, and relatively high to intermediate $\delta^{18} \mathrm{O}$ values $(+13.86 \%$ ), which are also close to ancient marine values. Likewise, it is noted that the Kert River and well no. 11 are two waters with low values of $\delta^{34} \mathrm{~S}$ and $\delta^{18} \mathrm{O}$. The same feature was observed in Messinian and Eocene basins in Spain. As suggested by Taberner et al. (2000) who explained the decrease in ${ }^{34} \mathrm{~S}$ and ${ }^{18} \mathrm{O}$ values at the basin restriction and reservoir effect due to fractionation during precipitation.

The considerable difference of data indicates mixing of sulphate from at least three different sources.

The first one is dissolution of messinian evaporates within the reservoir represented by the well 5 and characterized by high value of ${ }^{34} \mathrm{~S}$ and rich in sulphate. The second lower concentration source was seemingly derived by the oxidation of pyrite or some other ${ }^{34} \mathrm{~S}$ depleted sulphide mineral from metamorphic massif of Temsamane, which play a dilution role. The third one is the sulphate carried by Kert River. The water from wells 6 and 7 is intermediate between the water from the leaching of messinian unit and water from the metamorphic massif of Temsamane, with a dominance of this latter.

An important question emerges: why did this difference of ${ }^{34} \mathrm{~S}$ composition and $\mathrm{SO}_{4}{ }^{2-}$ concentration in $\mathrm{C}$ and $\mathrm{D}$ groups despite both is situated close Kert River? The water of group $\mathrm{C}$ has an isotopic signature low but is richer in sulphate compared with the water of group D. This is explained by the fact that the group $\mathrm{C}$ is found in an open system in relation to the external source of sulphate which is the Kert River, while group D is in a closed system with respect to the sulphate.

\section{Conclusion}

The $\mathrm{O}$ and $\mathrm{H}$ isotope data obtained in this study show that all the water wells and Kert River are not situated along the MWL. This demonstrates the rapid isotopic enrichment which can occur as a result of evaporation in this arid setting. The low $d$-excess values $(<10 \%$ ) in all part of the Kert area suggest that there is significant evaporation of rainwater leaving the residual groundwater with lower values of $d$-excess. Also $d$-excess distinction suggests different recharge sources under different climatic conditions.

$\delta^{18} \mathrm{O}_{\mathrm{SO}_{4}}$ values of the sulphate in the waters are a function of the sulphate sources and not the waters. It seems reasonable to assume that $\mathrm{SO}_{4}{ }^{2-}-\delta^{18} \mathrm{O}$ controls $\mathrm{SO}_{4}{ }^{2-}$ sources, because any correlation exists between ${ }^{18} \mathrm{O}_{\mathrm{H}_{2} \mathrm{O}}$ and ${ }^{18} \mathrm{O}_{\mathrm{SO}_{4}}$. Variation in $\delta^{34} \mathrm{~S}$ values gives some clues on the origin of dissolved sulphates. Then, $\delta^{34} \mathrm{~S}$ data show that aqueous $\mathrm{SO}_{4}{ }^{2-}$ seems to have three sources; the most concentrated $\mathrm{SO}_{4}{ }^{2-}$ seems to have been sourced from Miocene marls and Kert River. A lower concentration source was seemingly derived by the oxidation of pyrite within Temsamane metamorphic massif.

It appears from these results that the sulphate of groundwater in the Kert aquifer has the same genetic link, which is the dissolution of messinian evaporates, but the acquisition mode of geochemical composition seems to be different, and depending on the considered sector in which each well is situated. However, a mixing process happened between aquifer and water mass derived from metamorphic massif of Temsamane in the north, and the water from the Kert River in the south. In conclusion, isotope tracing permits to propose four geochemical basins each of them showing a different process affecting sulphate. This hypothesis is consistent with geologic data and also hydrogeological and hydrochemical data.

Acknowledgments The present work is part of $\mathrm{PhD}$ thesis of the first author granted by the Spanish Agency of International Cooperation for the Development (AECID). The project has been funded by the Spanish Ministry of Science and Innovation through the project CGL2009-07025. The authors greatly appreciate the analytical support of the Scientific-Technical Services of the University of Barcelona. The authors thank Juan José Pueyo for the helpful comments during the preparation of the manuscript. The anonymous reviewers and the associate editor had suggested constructive improvements to the original manuscript. The authors are also thankful to them. 


\section{References}

Ait Brahim L, Chotin P, Hinaj S, Abdelouafi A, El Adraoui A, Nakcha C, Dhont M, Charroud M, Sossey Alaoui F, Amrhar M, Bouaza A, Tabyaoui H, Chaouni A (2002) Paleostress evolution in the Moroccan African margin from Triassic to Present. Tectonophysics 357:187-205

Algamal SA (2011) An assessment of recharge possibility to NorthWestern Sahara. Aquifer System (NWSAS) using environmental isotopes. J Hydrol 398:184-190

APHA (1985) Standard methods for the examination of water and wastewater, 16th edn. American Public Health Association, Washington

Azdimousa A (1999) Géodynamique et exhumation des bordures meridionales de la mer d'alborane entre le massif de Beni Bouzera et le Cap des trois Fourches (Rif, Maroc). Apports de la méthode d'analyse par traces de fission. $\mathrm{PhD}$ thesis, Univ of Mohamed I

Azdimousa A, Jabaloy A, Asebriy L, Booth-Rea G, González-Lodeiro F, Bourgois J (2007) Lithostratigraphy and structure of the Temsamane unit (eastern external Rif, Morocco). Revista de la Sociedad Geológica de España 20(3-4):187-200

Berner ZA, Stuben D, Leosson MA, Klinge H (2002) S and O isotopic character of dissolved sulphate in the cover rock aquifers of a Zechstein salt dome. Appl Geochem 17:1515-1528

Cappa CD, Hendricks MB, DePaolo DJ, Cohen RC (2003) Isotopic fractionation of water during evaporation. J Geophys Res Atmos 108(D16): 1-10

Carlier Ph (1973) Carte hydrogólogique au 1/50000 de la plaine du moyen Kert (Province de Nador, Maroc nord-oriental). Notes Mém Serv Géol Maroc N ${ }^{\circ} 250$ bis p72

Chaouni Alia A (2001) Etude hydrogéologique et hydrochimique de la plaine côtière de Bou-Areg (Maroc nord-oriental). $\mathrm{PhD}$ thesis, Univ of Gent, Belgique

Clark I, Fritz P (1997) Environmental isotopes in hydrogeology. Lewis Publishers, New York, p 328

Claypool GE, Holser WT, Kaplan IR, Zak I (1980) The age curves of sulphur and oxygen isotope in marine sulfate and their mutual interpretations. Chem Geol 28:199-260

Craig H (1961) Isotopic variation in meteoric waters. Science 133(3465):1702-1703

Dansgaard W (1964) Stable isotopes in precipitation. Tellus 4:438-467. Department of Water, 2010. Pilbara Regional Water Plan 2010-2030. Department of Water, Western Australia, Perth

Dogramaci SS, Herczeg AL, Schiff SL, Bone Y (2001) Controls on $\delta^{34} \mathrm{~S}$ and $\delta^{18} \mathrm{O}$ of dissolved sulfate in aquifers of the Murray Basin, Australia and their use as indicators of flow processes. Appl Geochem 16:475-488

Eastoe CJ, Hutchison WR, Hibbs BJ, Hawley J, Hogan JF (2010) Interaction of a river with an alluvial basin aquifer: stable isotopes, salinity and water budgets. J Hydrol 395:67-78

Elgettafi M (2011) Caractérisation des processus de la salinisation des eaux souterraines de la plaine de Kert, Maroc Nord Oriental: approches hydrogéologique, géochimique et géophysique. $\mathrm{PhD}$ thésis, University Cadi Ayyad of Marrakech

Elgettafi M, Himi M, ElMandour A, Casas A (2011) Hydrochemical characterisation of groundwater salinity in Kert aquifer, NE Morocco. Geografia Tech 2:15-22

Elgettafi M, Elmandour A, Himi M, Casas A, Elhaoudi B (2012) Messinian salinity crisis impact on the groundwater quality in Kert aquifer NE Morocco: hydrochemical and statistical approaches. Int J Water Res Environ Eng 4(11): 339-351
Feinberg H (1986) Les series tertiaires des zones externes du Rif (Maroc) (Areas tertiary series of external Rif, Morocco). Notes Mém Serv Géol Maroc 315:192

Frizon de Lamotte D (1985) La structure du Rif oriental (Maroc): rôle de la tectonique longitudinale et importance des fluides (Oriental Rif structure, Morocco: longitudinal tectonic role and fluid importance). $\mathrm{PhD}$ thesis, University of Pièrre et Mairie Curie, Paris

Gat JR (1971) Comment on the stable isotope method in the regional groundwater investigation. Water Resour Res 7:980-993

Gat JR (1981) Groundwater, in stable isotope hydrology: deuterium and oxygen-18 in the water cycle. In:Gat JR, Gonfiantini R (eds) Technical reports series, vol 210. International Atomic Energy Agency, Vienna, pp 223-240

Gat JR (1995) Stable isotopes of fresh and saline lakes. In: Lerman A, Imboden D, Gat $\mathrm{J}$ (eds) Physics and Chemistry of Lakes. Springer, pp 139-165

Gonfiantini R (1986) Environmental isotopes in lake studies. Elsevier, Amsterdam, pp 113-168

Haq BU, Hardenbol J, Vail PR (1987) Chronology of fluctuating sea levels since the Triassic. Science 235:1159

Hervouet A (1985) Evolution tectono-sédementaite de l'avant fosse rifaine du Maroc oriental au Miocène. Bulletin de l'Institut Scientifique Rabat 9:81-89

IAEA/WMO (2006) Global network of isotopes in precipitation. The GNIP database. http://isohis.iaea.org

Krouse HR, Mayer D (1999) Sulfur and oxygen isotopes in sulphate. In: Cook P, Herczeg AL (eds) Environmental tracers in subsurface hydrology. Kluwer, Boston, pp 195-232

Levin M, Gat JR, Issar A (1980) Precipitation, flood and groundwaters of the Negev highlands: an isotopic study of desert hydrology. In: Proceedings of an advisory group meeting, arid zone hydrology: investigations with isotope techniques. International Atomic Energy Agency, IAEA-AG-158/1, Vienna, Austria

Moller P, Rosenthal E, Geyer S, Guttman J, Dulski P, Rybakov M, Zilberbrand M, Jahnke C, Flexer A (2007) Hydrochemical processes in the lower Jordan valley and in the Dead Sea area. Chem Geol 239:27-49

Otero O, Soler A, Canals À (2008) Controls of $\delta^{34} \mathrm{~S}$ and $\delta^{18} \mathrm{O}$ in dissolved sulphate: learning from a detailed survey in the Llobregat River (Spain). Appl Geochem 32:1166-1185

Rouchy JM, Caruso A (2006) The Messinian salinity crisis in the Mediterranean basin: a reassessment of the data and an integrated scenario. Sed Geol 188-189:35-67

Sultan M, Sturchio NC, Hassan FA, Hamdan MAR, Mahmood AM, ElAlfy Z, Stein T (1997) Precipitation source inferred from stable isotopic composition of Pleistocene groundwater and carbonate deposits in the Western Desert of Egypt. Quat Res 48:29-37

Taberner C, Cendon DI, Pueyo JJ, Ayora C (2000) The use of environmental markers to distinguish vs. continental deposition and to quantify the significance of recycling in evaporate basins. Sed Geol 137:213-240

Vengosh A, Hening S, Ganor J, Mayer B, Weyhenmeyer CE, Bullen TD, Payten A (2007) New isotopic evidence for the origin of groundwater from the Nubian Sandstone Aquifer in the Negev, Israel. Appl Geochem 22:1052-1073

Yechieli Y, Starinsky A, Rosenthal E (1992) Evolution of brackish groundwater in a typical arid region: Northern Arava Rift Valley, Southern Israel. Appl Geochem 7:361-374

Zeryouhi I (1971) Rapport sur l'execution de deux forages de reconnaissances et d'essais dans la plaine du Moyen Kert 
(Report on the execution of recognition drilling and testing in the Central Middle Kert). Rapp. Inéd. MTPC/DH/DRE. Rabat, p 5
Zielhofer C, Faust D, Linstadter J (2008) Late Pleistocene and Holocene alluvial archives in the Southwestern Mediterranean: changes in fluvial dynamics and past human response. Quat Int 181:39-54 